Available online at GSC Online Press Directory

GSC Biological and Pharmaceutical Sciences

e-ISSN: 2581-3250, CODEN (USA): GBPSC2

Journal homepage: https://www.gsconlinepress.com/journals/gscbps

(RESEARCH ARTICLE)

\title{
Assessment of fungi incidence, seed germination and aflatoxin contamination of groundnut (Arachis hypogaea L.) from Lagos, Nigeria.
}

\author{
Ekhuemelo Chigoziri* and Olorunlagba Bolanle Temitope \\ Department of Crop and Environmental Protection, Federal University of Agriculture, P.M.B. 2373 Makurdi, Benue State, \\ Nigeria.
}

Publication history: Received on 15 June 2020; revised on 23 June 2020; accepted on 25 June 2020

Article DOI: https://doi.org/10.30574/gscbps.2020.11.3.0185

\begin{abstract}
Groundnut (Arachis hypogaea L.) is a legume of high nutritive and market value usually contaminated by aflatoxin. The evaluation of aflatoxin contamination of groundnut entering the food system through the markets is necessary to ascertain the quality of the groundnut sold and subsequently advice groundnut consumers. The study assessed the aflatoxin $\mathrm{B}_{1}\left(\mathrm{AfB}_{1}\right)$ contamination levels in groundnut sold in some markets in Lagos, Nigeria. Groundnut seeds were sampled from five Local Government Areas (L. G.A) of Lagos State namely: Agege, Eti-Osa, Ifako Ijaye, Ketu and Oshodi. The samples were packaged in envelopes and transported to the Mycotoxin laboratory of the Federal University of Agriculture, Makurdi, Nigeria for assessment of the fungi infections, seed germination and aflatoxin contamination levels. The experiment for the assessment of fungi infecting and germination of groundnut seeds was laid out in a completely randomized design in ten replicates. Detection of $\mathrm{AfB}_{1}$ present in the groundnut samples was done using Enzyme Linked Immunesorbent Assay (ELISA) method in three replicates. Result showed that Aspergillus flavus Link was the most frequently isolated fungi with $46 \%$ incidence, Lasiodiplodia theobromae Pat. had $20 \%$ incidence, Aspergillus niger van Tiegh with $11 \%$ and Fusarium verticollioides Sacc. $7 \%$ incidence. The moisture content of groundnut seeds ranged between $7.20 \%$ and $6.53 \%$. Aflatoxin $\mathrm{B}_{1}$ concentrations in groundnut samples was highest in Eti Osa LGA $(5.11 \mu \mathrm{g} / \mathrm{kg})$ while Oshodi LGA had the least concentration $(3.09 \mu \mathrm{g} / \mathrm{kg})$. Groundnut samples from the five Local Government Areas of Lagos State were contaminated with $\mathrm{AfB}_{1}$ at concentration levels below the safe limits for human consumption and health of $20 \mu \mathrm{g} / \mathrm{kg}$. Management of fungi infection on the field is recommended to prevent field to store contamination of groundnut seeds.
\end{abstract}

Keywords:Groundnut; Aflatoxin; Fungi infections; Market; Contamination; Incidence.

\section{Introduction}

Groundnut (Arachis hypogaea L.) is an important oilseed and cash crop rich in proteins, fats and minerals. In Nigeria, groundnut is consumed both locally and as export crop to other countries.

It is used for domestic and industrial purposes, cooking, as confectionery product, as snacks together with popcorn popularly called 'guguru ati epa' among the Yorubas of Lagos State, Nigeria. Roasted groundnut is also used for groundnut cakes known as 'kuli kuli', production of groundnut oil used in cooking, for soap production and as body cream [1].

Nigeria is the largest producer of groundnut in West Africa with about $10 \%$ of the global groundnut production [2].Groundnut consumption contributes about ten percent of the calorie intake of Nigerian diets and is also a source of income for farmers in North Central Nigeria [3, 4].

\footnotetext{
* Corresponding author: Ekhuemelo Chigoziri; Phone: +234 (0)7031332667; Email: chiekhuemelo@gmail.com
} 
Groundnuts are regarded as a good substrate for aflatoxin contamination especially when the seeds are not properly dried to moisture content below $10 \%$ and temperature below $25^{\circ} \mathrm{C}$ before storage[5]. The fungal species causing aflatoxin contamination could penetrate the hard shell of the groundnut to commence biodeterioration processes without necessarily showing any form of mouldiness [6]. This results in microbial biodeterioration of food crops leading to food and economic losses, thereby reducing the export value of crops[6, 7]. Aflatoxin contamination was responsible for the import ban of five commodities including groundnut by the European Union resulting in loss of $\$ 671.1$ billion in import revenue in Nigeria. At a prevalence rate of $20 \mu \mathrm{g} / \mathrm{Kg}$, the monetized burden of aflatoxin contamination was between $\$ 112$ and $\$ 942$ million which was about $0.5 \%$ of Nigeria's GDP in 2010 [3]. Similarly, Nigeria experienced export sanctions as a result of aflatoxin contamination of groundnut and some other commodities in 2016 [8].

Aflatoxin $\mathrm{B}_{1}$ which is the most common and most toxic mycotoxin hazardous to humans and animals worldwide is mainly produced by Aspergillus flavus and Aspergillus parasiticus[8]. Aflatoxins in human diet may lead to cancer, liver diseases, hepatocarcinogenicity, hepatitis B viral infection, immunosuppression interference, stunted growth and may lead to death $[9,10$, and 11]. Aflatoxin contamination is responsible for the suppression of human and animal immune system and can lead to increase in the viral load of HIV and AIDS patients [4]. Fatal outbreaks of toxicities resulting from aflatoxins have been reported in Nigeria and elsewhere in Africa [12, 13].

Although groundnut is not commonly cultivated in Lagos State Nigeria, it is on popular demand and it is usually consumed together with popcorn as a delicacy and snack. There is low awareness and paucity of information on aflatoxin $\mathrm{B}_{1}$ contamination of groundnut sold in some local markets in Lagos, Nigeria. This has necessitated the assessment of fungal and aflatoxin contamination of locally consumed groundnut to ascertain its safety for consumption. This study was therefore aimed at assessing the fungi incidence, seed germination and aflatoxin $\mathrm{B}_{1}$ contamination levels in groundnut sold in some markets in five LGAs of Lagos State, Nigeria.

\section{Material and methods}

\subsection{The study area}

The study was conducted in selected markets in five out of the twenty LGAs of Lagos State where groundnut is sold namely: Agege (Agege market), Eti Osa (Ajah market), Ifako Ijaye (Abule Egba market), Ketu (Mile 12 International market), Oshodi (Arena market). Lagos State is located in the South West of Nigeria between longitude $3^{\circ} 23^{\prime}-3^{\circ} 39^{\prime} \mathrm{E}$ and latitude $6^{\circ} 27^{\prime}-6^{\circ} 45^{\prime} \mathrm{N} 11 \mathrm{~m}$ above sea level. Lagos State shares borders with Ogun State on the North and East, the Atlantic Ocean in the South and the Republic of Benin on the West.

\subsection{Sample collection and preparation for analysis}

Forty five groundnutshelled groundnut seed samples were collected from nine marketers in each of the five LGAs of Lagos State in June 2018.The samples were packaged in envelopes and transported to the Mycotoxin laboratory of the Federal University of Agriculture, Makurdi, Nigeria for assessment of the seed germination, fungi incidence and aflatoxin contamination levels.

\subsection{Seed health testing and germination}

Seed health testing was done by blotter method. The experiment was a completely randomized design (CRD) with ten replicates. The groundnut seeds were sterilized in $10 \%$ sodium hypochlorite solution for one minute. One hundred seeds were used for each LGA giving a total of 500 seeds. Ten seeds were placed in a $9 \mathrm{~cm}$ Petri dish containing moist double layer filter paper. After seven days, the mycelium growing out of the seeds were inoculated into fresh Petri dishes and incubated for seven days to obtain pure cultures. Fungal organisms were identified by preparing slides and viewing spores under compound microscope (x40 magnifications) for the presence of fungi. Isolated fungi were identified using reference manual [14]. The number of germinated and infected seeds was recorded for each LGA.

\subsection{Detection of Aflatoxin $B_{1}$ on groundnut seeds}

Detection of Aflatoxin $\left(\mathrm{AfB}_{1}\right)$ quantity present in the groundnut samples was done using the ELISA method at the Aflatoxin laboratory of the Department of Crop and Environmental Protection of the Federal University of Agriculture, Makurdi, Nigeria. The experiment was laid out in a completely randomized design with three replications.

\subsection{Detection and quantification of Aflatoxin $\left(\mathrm{AfB}_{1}\right)$ from groundnut seed samples.}

Detection of Aflatoxin $\left(\mathrm{AfB}_{1}\right)$ quantity present in the groundnut samples collected from the study area was done using the Enzyme Linked Immunosorbent Assay (ELISA) method. 
Twenty grams (20g) out of one hundred grams (100 g) of blended groundnut seed samples obtained from each LGA were triturated with $100 \mathrm{ml}$ of $70 \%$ methanol containing $5 \mathrm{~g}$ Potassium Chloride in Waring Commercial blender to make a homogeneous mixture. The resulting extract was transferred into a $250 \mathrm{ml}$ conical flask and shaken on an orbital (Model ORBI-Shaker) shaker for 30 minutes and filtered using Whatman No 1 filter paper. It was then diluted in 1:10 phosphate buffer saline in Tween-20 (1 ml of extract and $9 \mathrm{ml}$ of buffer) and left to stand for 10 hours and analyzed.

The determination of aflatoxin contamination of groundnut samples was done by adding $1.5 \mu$ of AfB - $_{1}$-BSA congugate to $15 \mathrm{ml}$ of carbonate Buffer, which was vortexed and the mixture poured into wells and incubated for one hour at $37^{\circ} \mathrm{C}$. One hundred and fifty microlitres $(150 \mu \mathrm{l})$ of BSA was added into all the wells and incubated for 30 minutes. A mixture of BSA $(1 \mathrm{ml})$ and $\mathrm{AfB}_{1}$ standard $(2.5 \mu \mathrm{l})$ was vortexed and $100 \mu \mathrm{l}$ poured into Standard wells. Six millilitre of BSA was mixed with $1 \mu \mathrm{l}$ of Anti- Serum. Fifty microlitre $(50 \mu \mathrm{l})$ of the mixture was pipette into both the Standard and sample wells. Ninety microlitre $(90 \mu \mathrm{l})$ of BSA and $10 \mu \mathrm{l}$ of the initial sample extract were added into all the sample wells. One hundred microlitre $(100 \mu \mathrm{l})$ of the diluted Anti-Serum was added to some of the Standard wells and incubated for an hour.

Ten millilitre $(10 \mathrm{ml})$ of BSA was mixed with $2.5 \mu \mathrm{l}$ of Anti- rabbit and $150 \mu \mathrm{l}$ of the mixture poured into all the wells and incubated for 1 hour for $37^{\circ} \mathrm{C}$. One hundred and fifty microlitre (150 $\left.\mu \mathrm{l}\right)$ of a mixture obtained by dissolving fifteen milligrams (15mg) of PNPP in $30 \mathrm{ml}$ of $10 \%$ diethanolamine at pH 9.8 was poured into all the wells, incubated for twenty minutes and $\mathrm{AfB}_{1}$ levels quantified using a spectrophotometer.

\subsection{Data Collection}

Aflatoxin contamination was quantified in microgram per kilogram $(\mu \mathrm{g} / \mathrm{Kg})$ using a spectrophotometer. Data on percentage germination was recorded as the number of germinated seeds relative to the total number of seeds plated expressed as a percentage at 5, 6,7 and 10 days after incubation (DAI). Percentage infection was recorded as the number of infected seeds relative to the total number of seeds incubated expressed as a percentage.

\subsection{Data Analysis}

Data were subjected to analysis of variance using GenStat version 9.0 statistical software. Significant means were separated using Fishers least significant difference (F-LSD) at 5\% level of probability.

\section{Results}

Table 1 shows the aflatoxin $\mathrm{B}_{1}$ concentration and moisture content of groundnut samples from five LGAs of Lagos State, Nigeria. There was no significant difference $(P>0.05)$ in the moisture content of groundnut samples from the five LGAs with the moisture content of groundnut samples ranging between 6.53 and $7.20 \%$ across the LGAs tested. The concentration of $\mathrm{AfB}_{1}$ detected in groundnut seeds was significantly higher $(\mathrm{P}<0.05)$ in Eti osa LGA with $5.11 \mu \mathrm{g} / \mathrm{Kg}$ and Ketu LGA with $5.09 \mu \mathrm{g} / \mathrm{Kg}$ compared with Ifako $(4.22 \mu \mathrm{g} / \mathrm{Kg})$, Agege $(4.12 \mu \mathrm{g} / \mathrm{Kg})$ and Oshodi with the lowest concentration of $3.09 \mu \mathrm{g} / \mathrm{Kg}$.

Table 1Aflatoxin contamination and moisture content of groundnut samples from five LGAs of Lagos State, Nigeria

\begin{tabular}{lll}
\hline LGA & Aflatoxin B $\mathbf{1}(\boldsymbol{\mu g} / \mathbf{K g})$ & Moisture Content $(\%)$ \\
\hline Agege & 4.12 & 6.97 \\
Eti osa & 5.11 & 6.87 \\
Ifako & 4.22 & 6.53 \\
Ketu & 5.09 & 6.83 \\
Oshodi & 3.09 & 7.20 \\
\hline LSD (0.05) & 0.02 & NS \\
\hline
\end{tabular}

The interactive effect of incidence of fungi and the five LGAs of Lagos State from which they were isolated is presented in Table 2. The incidence of Aspergillus flavus was significantly $(\mathrm{P}<0.05)$ higher with a mean incidence of $46.00 \%$ compared with the incidence of L. theobromae (20.00\%), A. niger (11.00\%)and $F$. verticollioides with the least mean incidence of $7.00 \%$. Although location had no significant $(\mathrm{P}>0.05)$ effect on the incidence of fungi on groundnut seeds, Agege LGA had the highest mean fungi incidence of $25.00 \%$ followed by Oshodi $23.75 \%$, Eti Osa $21.00 \%$, Ketu 18.00 $\%$ and Ifako Ijaye with the least mean incidence of $17.25 \%$. 
Table 2 Interactive effect of fungi incidence on groundnut seeds and the five Local Government Areas of Lagos State sampled.

\begin{tabular}{llllll}
\hline Location/Fungi & A.flavus & A. niger & L. theobromae & F. verticollioides & Location mean \\
\hline Agege & 43.00 & 15.00 & 29.00 & 13.00 & 25.00 \\
Eti Osa & 24.00 & 15.00 & 36.00 & 9.00 & 21.00 \\
Ifako Ijaye & 41.00 & 15.00 & 11.00 & 2.00 & 17.25 \\
Ketu & 54.00 & 8.00 & 5.00 & 5.00 & 18.00 \\
Oshodi & 67.00 & 0.00 & 21.00 & 7.00 & 23.75 \\
\hline Fungi Mean & 46.00 & 11.00 & 20.00 & 7.00 & \\
\hline
\end{tabular}

The percentage infection of groundnut seeds from the five sampled locations is shown in Figure 1. The fungal infection of groundnut seeds was not significantly different $(P>0.05)$ at 4 and 5 days after incubation across the five LGAs with groundnut samples from Ifako Ijaye recording the least fungal infection of $20.00 \%$ and $34.6 \%$ infection respectively for the two days.

At 6 and 7 days after incubation (DAI) the groundnut seeds, groundnut samples from Ifako Ijaye had significantly $(\mathrm{P}<$ 0.05 ) lower infection (37.9\%) compared with the groundnut samples from all other locations which were statistically similar.At $10 \mathrm{DAI}$, the percentage infection of groundnut samples was not significantly different(P $>0.05)$ however samples from Agege LGA had the least percentage infection of $44.20 \%$ followed by samples from Ifako Ijaye with 50.00 $\%$ infection, Ketu recorded $84.60 \%$ infection, Eti Osa recorded $90.80 \%$ infection while Oshodi LGA recorded the highest fungal infection of $95.40 \%$.

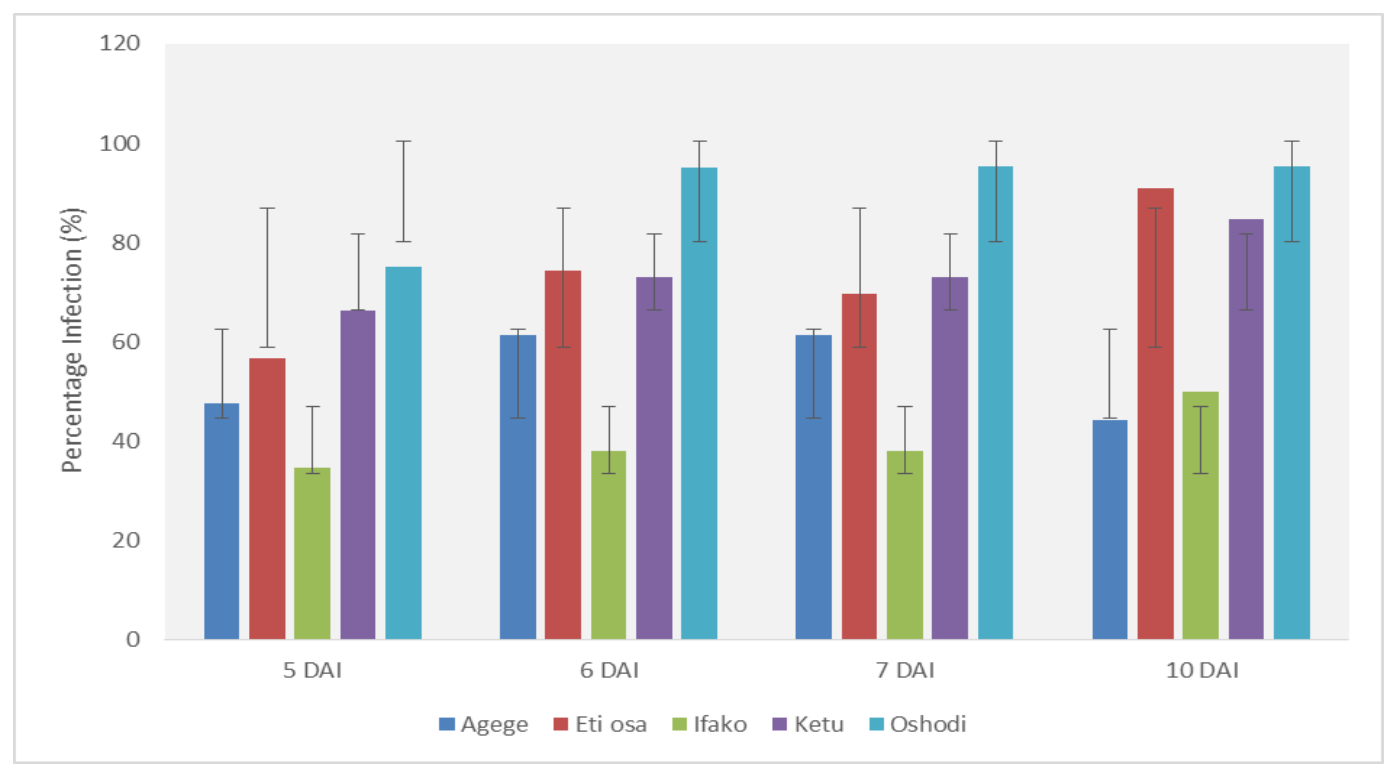

Figure 1 Percentage infection of groundnut seeds from five LGAs of Lagos State.

Figure 2 shows the percentage germination of groundnut seeds from the five LGAs of Lagos State. The figure shows a decline in seed germination across the LGAs during the period of incubation. Seed germination was highest in seed samples from Ifako Ijaye LGA which had $77.5 \%$ of seeds germinated 4 DAI and this reduced to $50.0 \%$ at 10 DAI while the least germination of groundnut seeds were recorded in seeds from Oshodi LGA with $36.2 \%$ reducing to $4.6 \% 10$ DAI. 


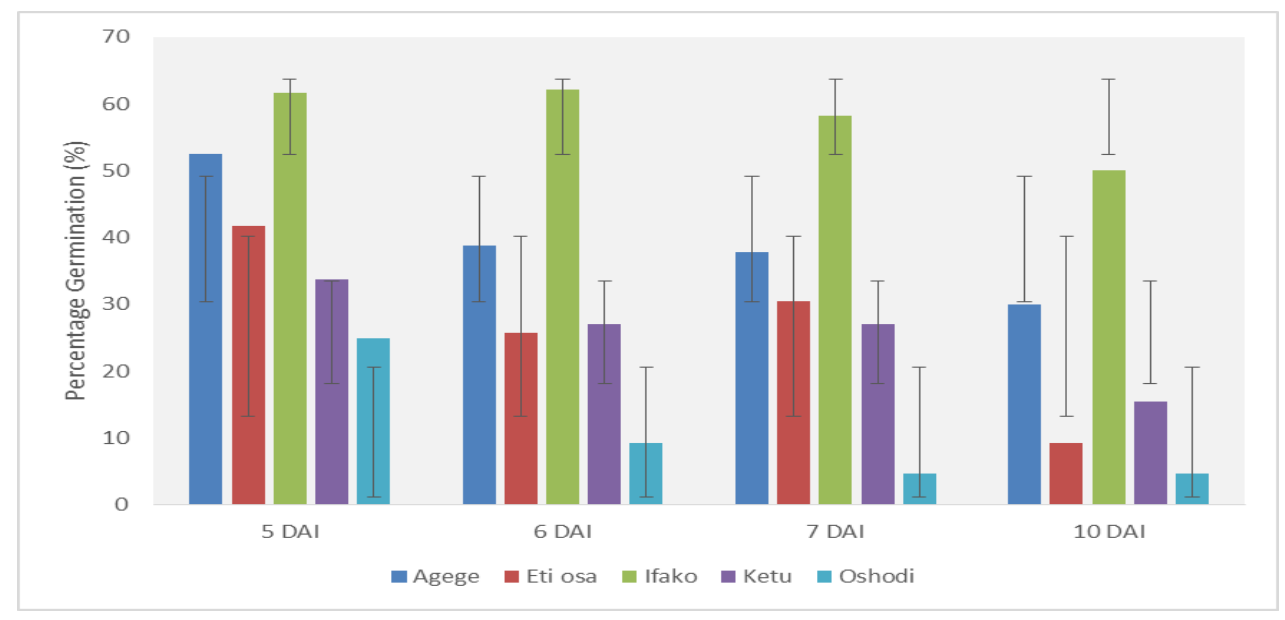

Figure 2Percentage germination of groundnut seeds from five LGAs of Lagos State.

\section{Discussion}

The present study recorded moderate fungi incidence and low $\mathrm{AfB}_{1}$ concentration with Aspergillus flavus recording the highest incidence. This finding agrees with the report of $[15,16]$ which identified Aspergillus genera as the prevalent fungal genera infecting groundnut seeds. The report of [17] observed that infection and contamination of groundnut seeds by Aspergillus can occur either on the field or at post-harvest. [18] reported the susceptibility of seeds stored at high temperature and relative humidity to fungal infection and mycotoxin contamination. Similarly [12] reported Aspergillus to be typical storage fungi that grow in relatively dry conditions. [19] reported that Aspergillus and Fusarium apart from being toxic to humans and animals, primarily affects seed quality, viability, germination and seedling vigour. The presence of these fungi may result in the development of plant disease symptoms when infected seeds are planted. Continuous cropping of groundnut on a piece of land for many seasons is also reported to affect the incidence of $A$. flavus and consequently the amount of aflatoxin produced on groundnut harvested from such plots [12].

Aspergillus flavus is known to be the main producer of aflatoxin which are carcinogenic [20]. The fungus has the ability to produce a number of enzymes which enables the fungus to develop and produce toxin on a wide variety of stored grains such as wheat, peanuts, soybeans, corn, groundnut and oil foods [21]. Aspergillus flavus isolates is reported to produce aflatoxins $B_{1}, B_{2}$ and cyclopiazonic acid (CPA), with some strains producing $G_{1}$ and $G_{2}$ aflatoxin [22]. Aflatoxins in foods are converted to aflatoxin-8, 9-epoxide metabolite in the liver which may be responsible for many of the toxic effects in the body [23].

The isolation of A. flavus and A. niger in this study is in line with the report of [24] in which the two Aspergillus spp had the highest rate of occurrence among the isolated fungi. Also [25] reported A. flavus as the most dominant fungal species occurring on okra, tomato and pepper fruits from Accra. Similarly [26] and [27] also identified A. flavus as the most frequently isolated fungal species in spices and spice product. Furthermore, [8] identified A. flavus as a toxigenic strain of the genera Aspergillus that contaminates groundnut by the production of aflatoxin. Conversely, Aspergillus niger was reported as a secondary invader on eggplant [28]. Aspergillus niger is also reported to biosynthesize some types of fumonisins [13]. In addition [11] noted that the isolation of a potentially toxigenic fungi does not imply the presence of mycotoxins since some mycotoxins are produced by more than one fungal specie. Although [12] reported Fusarium as a field fungus, its isolation from the present study shows the possibility of field to store transmission. [29] reported $F$. verticillioides as an important pathogen frequently detected in rice seed and further noted a significant positive correlation between germination and $F$. verticillioides resulting in reduced germination leading to about $42 \%$ population reduction.

The studies of [2] and [12] agreed that the ambient conditions in tropical Africa favoured the optimum moisture content for the growth and toxin production of toxigenic fungi accounting for high prevalence of mycotoxins in Africa. The moisture content of groundnut seeds in this study ranged between $6.53 \%$ to $7.20 \%$ and this was below $10 \%$ which is the moisture content below which fungal growth is inhibited and seed viability is preserved. The report of [29] also showed a correlation between moisture content and the incidence of some Fusarium and Aspergillus species in rice seed. Although high seed moisture content between $12-14 \%$ is known to favour fungal infection, [12] and [30] reported the possibility of $A$. flavus growing on grains with lower moisture content. 
The incidence of $A$. flavus isolated from Oshodi LGA was highest $(67.00 \%)$ the LGA recorded the lowest aflatoxin concentration of $3.09 \mu \mathrm{g} / \mathrm{Kg}$. This finding corroborates the report of [27] which noted high fungi incidence and low aflatoxin $\mathrm{B}_{1}$ in West African pepper. This indicates the possibility of the presence of some atoxigenic strains of $A$. flavus in the groundnut sample from Oshodi LGA. Agbetiameh et al [31] reported that the atoxigenic L morphotype of $A$. flavus was common in groundnut samples and that the L morphotype could be utilized in the biocontrol of aflatoxin contamination in groundnut fields. Furthermore [32] isolated toxigenic A. flavus L strain producing aflatoxin from retailed raw and roasted groundnuts from South Western Nigeria with all samples exceeding the $20 \mu \mathrm{g} / \mathrm{Kg}$ limit for $\mathrm{AfB} 1$ recommended by the National Agency for Food and Drug Administration Control in Nigeria and $79 \%$ of samples recording $\mathrm{AfB}_{1}$ above the European Union limits of $4 \mu \mathrm{g} / \mathrm{Kg}$. The study of [33] noted that aflatoxin contamination of kuli kuli a snack made from groundnut in northern Nigeria was above the aflatoxin safe levels of $20 \mu \mathrm{g} / \mathrm{Kg} \mathrm{recommended} \mathrm{in}$ Nigeria. Similarly, [4] reported that $30 \%$ of groundnut seeds sold in local markets in Nigeria were contaminated with aflatoxins with 25-83 \% exceeding the permissible levels in Nigeria with higher aflatoxin levels in local varieties than in the improved varieties. The current study shows a decline in the aflatoxin levels in groundnut sold in some popular markets in Lagos, Nigeria.

The present study recorded reduction of seed germination count as a result of the increase in percentage fungi infection over time. This decrease could be attributed to damping off of seedlings leading to a reduction in the germination count as the experiment progressed. The report of [34] noted that fungi infection on stored seeds such as groundnut may reduce seed germination. The infection of seeds by fungi is reported to result in the production of mycotoxins and loss of seed quality [35]. According to [36] mycotoxins produced by fungal species affect germination and seedling growth. Hasan [37] also reported 50 \% reduction in seedling viability of wheat, barley and sorghum by aflatoxin noting that aflatoxin at concentrations higher than $10 \mu \mathrm{gm} \mathrm{L}-1$ resulted in the reduction of growth rate of hypocotyls after germination. Similarly, [30] reported a significant correlation between the presence of Fusarium verticillioides and poor germination in rice seed.

Atanda et al.[12] noted that total aflatoxin of which aflatoxin $\mathrm{B}_{1}$ is a constituent is a basis for the classification of product quality into high, medium and low quality produce and this classification was used for pricing of premium (high quality) and discount (poor quality) crop. Milicevic et al. [11] also agreed that the evaluation of mycotoxin and mycotoxingenic fungi aids in the determination of the quality of food and feed while [34] reported a relationship between seed borne pathogens and deterioration in the seed quality of groundnut seeds.

\section{Conclusion}

Seeds of groundnut from the five Local Government Areas of Lagos State, Nigeria were contaminated with AfB $_{1}$ at concentration levels below $20 \mu \mathrm{g} / \mathrm{Kg}$ which is the safe limits for human consumption in Nigeria. Aspergillus flavus recorded the highest percentage incidence followed by Lasiodioplodia theobromae, Aspergillus niger and Fusarium verticillioides. The presence of these fungi reduced germination percentage of groundnut seeds. Farm and store sanitation should be encouraged to reduce and further eliminate the incidence of aflatoxin contamination on groundnut sold in local markets in the study area.

\section{Compliance with ethical standards}

\section{Acknowledgements}

The authors appreciate the technologists in the aflatoxin laboratory of the Department of Crop and Environmental Protection of the Federal University of Agriculture, Makurdi, Nigeria for their technical support.

\section{Disclosure of conflict of interest}

The authors declared no conflict of interest.

\section{References}

[1] Ibrahim U, Ayinde BT, Dauda H and Mukhtar AA. (2013). Socio Economics factors affecting groundnut production in Sabon Gari LGA of Kaduna State, Nigeria. Int. J. of Food and Agr. Eco, 1(1), 41-48.

[2] Ajeigbe HA, Waliyar F, Echekwu CA, Ayuba K, Motagi BN, Eniayeju D and Inuwa A. (2014). A Farmer's Guide to Groundnut Production in Nigeria.Patancheru, Telangana, India: International Crops Research Institute for SemiArid Tropics, 36. 
[3] Ndenn J, Diedhiou P and Atanda 0. (2015). "The economic impact of aflatoxins in West Africa: the case of Gambia, Nigeria and Senegal". Partnership for Aflatoxin Control in Africa, 15.

[4] Vabi MB, Ogara I, Anjorin FT, Oluwabaniwo F, Alabi O, Ajeigbe HA and Denloye S. (2018). Aflatoxins in Nigerian Groundnut: Continuous Threat to Health, Agriculture and Foreign Trade. Policy Brief, 35, 4.

[5] Bankole and Adebanjo. (2003).

[6] Oyedele AO, Ezekiel, CN, Sulyok M, Adetunji MC, Warth B, Atanda 00 and Krska R. (2017). Mycotoxin risk assessment for consumers of groundnut in domestic markets in Nigeria. International Journal of Food Microbiology, 251, 24-32.

[7] Oluwafemi F and Da-Silva FA. (2009). Removal of aflatoxins by viable and heat-killed Lactobacillus species isolated from fermented maize. Journal of Applied Biosciences, 16, 871 - 876.

[8] Vabi MB, Eche CO, Mukhtar AA, Kunihya A, Alabi O, Adobe K, Ekefan EJ, Haruna SG, Motagi BN and Ajeigbe HA. (2016). Understanding and Managing Aflatoxin Contamination in the Groundnut Value Chain in Nigeria. International Crops Research Institute for the Semi-Arid Tropics, 9.

[9] Sweeney MJ and Dobson ADW. (1998). "Mycotoxin Production by Aspergillus, Fusarium of and Penicillium Species," Int. J. of Food Micro, 43(3), 141-158.

[10] Abbas HK, Zablotowicz RM, Horn BW, Philips NA, Johnson BJ, Jin X and AbelCA. (2011). Comparison of major control strains of non-toxigenic Aspergillus flavus for the reduction of aflatoxins and cyclopiazonic acid in maize. Food Additives and Contaminants Part A, 28, 198-208.

[11] Milicevic D, Nesic K and Jaksic S. (2015). Mycotoxin contamination of the food supply chain - Implications for one health programme. Procedia Food Science, 5, 187-190.

[12] Atanda O, Makun HA, Ogara IM, Edema M, Idahor KO, Eshiett ME and Oluwabamiwo BF. (2013). Fungal and Mycotoxin Contamination of Nigerian foods and feeds. In : Mycotoxin and Food Safety in Developing Countries, 38.

[13] Misihairabgwia JM, Ezekiel CN, Sulyokc M, Shephardd GS and Krska R. (2017). Mycotoxin contamination of foods in Southern Africa: A 10-year review (2007-2016).Critical Reviews in Food Science and Nutrition, 59(1), 43-58.

[14] Watanabe T. (2010). Pictorial atlas of soil and seed fungi: Morphologies of cultured fungi and key to species, 3rd edition. American Phytopathology Society press, United State of America, 404.

[15] Youssef MS, El-Maghraby OMO and Ibrahim YM. (2008). Mycobiota and Mycotoxins of Egyptian Peanut (Arachis hypogaea L.) Seeds. International Journal of Botany, 4(4), 349-360.

[16] Ekhuemelo C and Abu SO. (2018). Evaluation of the Aflatoxin contamination and proximate composition of groundnut (Arachis hypogaea L.) infected by Aspergillus spp. Nigerian Journal of Biotechnology, 35(2), 130-138.

[17] Ezekiel CN, Sulyok M, Warth B, Odebode AC and Krska R. (2012). Natural occurrence of mycotoxins in peanut cake from Nigeria. Food Control, 27, 338-342.

[18] Afolabi CG, Ezekiel CN, Ogunbiyi AE, Oluwadairo OJ, Sulyok M and Krska R. (2019). Fungi and mycotoxins in cowpea (Vigna unguiculata L) on Nigerian markets. Food Additives and Contaminants: Part B, 1-7.

[19] Ahmed AI and Jutta P. (2015). Mycotoxins: Producing Fungi and Mechanisms of Phytotoxicity. Agriculture, 5(3), 492-537.

[20] Rodrigues P, Soares C, Kozakiewicz Z, Paterson RRM, Lima N and Venâncio A. (2007).Identificationand characterization of Aspergillus flavus and Aflatoxins. Comm. Curr. Resource and Edu. Top. and Trends in Applied Microbiology, 527- 534.

[21] Centre for Disease Control and Prevention (CDC). (2004). Outbreak of Aflatoxin poisoning in Eastern and Central Provinces of Kenya. Morb. Mort. Weekly Report, 53 (34), 790-793.

[22] Scheidegger KA and Payne GA. (2003). Unlocking the Secrets Behind Secondary Metabolism: A Review of Aspergillus flavus from Pathogenicity to Functional Genomics. Journal of Toxicology and Toxin Reviews, 22 (2 and 3), 423- 459.

[23] Eaton DL and Gallagher EP. (1994). Mechanisms of aflatoxin carcinogenesis. Annual Review of Pharmacology, $34,275-301$. 
[24] Muhammad S, Shehu K and Amusa NA. (2004). Survey of the market diseases and aflatoxin contamination of tomato (Mill.) fruits in Sokoto, North Western Nigeria. Nutr and Food Science, 34, 72-76.

[25] Mensah JK and Owusu E. (2012). Capsicum annum L. (pepper), Abelmoschus esculentus L. Moench (Okra), and Lycopersicon esculentum Mill. (tomato) from Accra metropolis. African Journal of Food Science, 6(1), 1-7.

[26] Ahene RE, Odamtten GT and Owusu E. (2011). Fungal and bacterial contaminants of six spices and spice products in Ghana. African Journal of Environmental Science and Technology, 5(9), 633-640.

[27] Ezekiel CN, Fapohunda SO, Olorunfemi MF, Oyebanji AO and Obi I. (2013). Mycobiota and aflatoxin B1 contamination of Piper guineense (Ashanti pepper), P. nigrum L. (black pepper) and Monodora myristica (calabash nutmeg) from Lagos, Nigeria. International Food Resouirce Journal, 20(1), 111-116.

[28] Mbadianya JI, Echezona BC and Ugwuoke K. (2013). Pathogenicity of fungi associated with the leaf spot disease of Eggplant (Solanum aethiopicum L.) in a derived savannah zone. Journal of Agriculture and Veterinary Science, 2(4), 51-57.

[29] Kwaloe AD, Msuya DG, Nchimbi-Msolla S, Tokpah DP and Luther Z. (2018). Incidence of seed borne fungi in farm saved rice seeds, quality declared seed and certified seed in Morogoro Region in Tanzania. Journal of Plant Breeding and Crop Science, 10(7), 162-168.

[30] Ok HE, Kim DM, Kim D, Chung SH, Chung MS, Park KH and Chun HS. (2014). Mycobiota and natural occurrence of aflatoxin, deoxynivalenol, nivalenol and zearalenone in rice freshly harvested in South Korea. Food Control, 37, 284-291.

[31] Agbetiameh D, Ortega-Beltran A, Awuah RT, Atehnkeng J, Cotty PJ and Bandyopadhyay R. (2018). Prevalence of Aflatoxin Contamination in Maize and Groundnut in Ghana: Population Structure, Distribution, and Toxigenicity of the Causal Agents. Plant Disease, 102, 764-772.

[32] Afolabi CG, Ezekiel CN, Kehinde IA, Olaolu AW and Ogunsanya OM. (2014).Contamination of Groundnut in SouthWestern Nigeria by Aflatoxigenic Fungi and Aflatoxins in Relation to Processing. Journal of Phytopathology, 163(4), 279-286.

[33] Ayoade F and Adegbite TD. (2016). Microbiological screening of street-vended groundnut cake, Kulikuli and natural spices for reducing microbial contamination in the food snack. Int. J. Biol. Chem. Sci, 10(6), 2677-2691.

[34] Begum MAJ, Venudevan B and Jayanthi M. (2013). Storage Fungi in Groundnut and the Associate Seed Quality Deterioration- A Review. Plant Pathology Journal, 12, 127-134.

[35] Naqvi S and Zeeshan H. (2013). Combined efficacy of biologically synthesized silver nanoparticles and different antibiotics against multidrug-resistant bacteria. Int. J. Nanomed, 8, 3187.

[36] Koteswara RV, Girisham S and Reddy SM. (2014). Influence of different species of Penicillium and their culture filtrates on seed germination and seedling growth of sorghum. Journal of Biochemical Technology, 5(4):, 832837.

[37] Hasan HAH.(1999). Phytotoxicity of pathogenic fungi and their mycotoxins to cereal seedling viability. Mycopathologia, 148, 149-155.

\section{How to cite this article}

Ekhuemelo C and Olorunlagba BT. (2020). Assessment of fungi incidence, seed germination and aflatoxin contamination of groundnut (Arachis hypogaea L.) from Lagos, Nigeria. GSC Biological and Pharmaceutical Sciences, 11(3), $216-223$. 